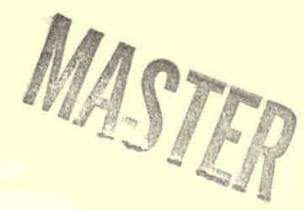

\title{
Offshore Heat Dissipation for Nuclear Energy Centers
}

Howard F. Bauman

OAK RIDGE NATIONAL LABORATORY OPERATED BY UNION CARBIDE CORPORATION - FOR THE DEPARTMENT OF ENERGY 


\section{DISCLAIMER}

This report was prepared as an account of work sponsored by an agency of the United States Government. Neither the United States Government nor any agency Thereof, nor any of their employees, makes any warranty, express or implied, or assumes any legal liability or responsibility for the accuracy, completeness, or usefulness of any information, apparatus, product, or process disclosed, or represents that its use would not infringe privately owned rights. Reference herein to any specific commercial product, process, or service by trade name, trademark, manufacturer, or otherwise does not necessarily constitute or imply its endorsement, recommendation, or favoring by the United States Government or any agency thereof. The views and opinions of authors expressed herein do not necessarily state or reflect those of the United States Government or any agency thereof. 


\section{DISCLAIMER}

Portions of this document may be illegible in electronic image products. Images are produced from the best available original document. 


\section{Printed in the United States of America. Available trom National Technical Information Service \\ U.S. Department of Commerce \\ 5285 Port Royal Road, Springfield, Virginia 22161 \\ Price: Printed Copy $\$ 4.50$; Microfiche $\$ 3.00$}

This report was prepared as an account of work sponsored by an agency of the United States Government. Neither the United States Government nor any agency thereof, nor any of their employees, contractors, subcontractors, or their employees, makes any warranty, express or implied, nor assumes any legal liability or responsibility for any third party's use or the results of such use of any information, apparatus, product or process disclosed in this report, nor represents that its use by such third party would not infringe privately owned rights. 
ORNL/TM-6435

Dist. Category UC-12

\author{
Contract No. W-7405-eng-26 \\ Engineering Technology Division
}

OFFSHORE HEAT DISSIPATION FOR NUCLEAR ENERGY CENTERS

Howard F. Bauman

\author{
Date Published - September 1978 \\ Prepared by the \\ OAK RIDGE NATIONAL LABORATORY \\ Oak Ridge, Tennessee 37830 \\ operated by \\ UNION CARBIDE CORPORATION \\ for the \\ DEPARTMENT OF ENERGY
}




\section{THIS PAGE}

\section{WAS INTENTIONALLY \\ LEFT BLANK}


CONTENTS

Page

SUMMARY AND CONCLUSIONS . . . . . . . . . . . . . . . iv ACKNOWLEDGMENTS . . . . . . . . . . . . . . . . . . . . viii LIST OF FIGURES . . . . . . . . . . . . . . . . . . . ix LIST OF TABLES . . . . . . . . . . . . . . . . . . . ix ABSTRACT .......................... . . . 1

1. INTRODUCTION . . . . . . . . . . . . . . . . . . . 1

2. ADVANTAGES AND IMPACTS OF ONCE-THROUGH COOLING . . . . . . . 2

2.1 Water Temperatures . . . . . . . . . . . . . 2

2.2 Atmospheric Effects . . . . . . . . . . . . . . . 4

2.3 Environmental Acceptance............... 4

3. DESIGN CONSIDERATIONS FOR AN OFFSHORE HEAT DISSIPATION

SYSTEM . . . . . . . . . . . . . . . . . . . . 5

4. CONCEPT FOR AN OFFSHORE HEAT DISSIPATION SYSTEM . . . . . . . 7

4.1 Intake . . . . . . . . . . . . . . . . . 9

4.2 Diffusers . . . . . . . . . . . . . . 9

4.3 Pumphouse .................. . . 10

4.4 Plant Layout . . . . . . . . . . . . . . 10

5. ENVIRONMENTAL EFFECTS . . . . . . . . . . . . . . 10

5.1 Impacts of Construction . . . . . . . . . . . . 10

5.2 Physical Effects of Operation . . . . . . . . . . 11

5.3 Effects of Operation on Aquatic Biota . . . . . . . 15

6. ECONOMICS . . . . . . . . . . . . . . . . 22

6.1 Current offshore System Designs . . . . . . . . . . 22

6.2 Costs of an NEC System . . . . . . . . . . . . 24

6.3 Water Conduits . . . . . . . . . . . . 25

6.4 Water Distribution . . . . . . . . . . . . . 25

REFERENCES . . . . . . . . . . . . . . . . . . . . 26 
SUMMARY AND CONCL.USSTONS

\section{SUMMARY}

The Nuclear Energy Center (NEC) is a concept for siting a large number of nuclear power plants at a common location. It appears feasible to utilize the ocean or other large water bodies for the dissipation of the large quantity of reject heat from an NEC.

Once-through cooling affords the advantages of higher thermal efficiencies and minimal loss of summer peak generating capacity compared to closed-cycle systems, and the problems of atmospheric heat dissipation are largely avoided. Depending on the land area found necessary for atmospheric heat dissipation systems, an NEC with once-through cooling could require a substantially smaller land area.

The main environmental impacts of once-through cooling are effects on ecosystem structure and function through (1) increase in the temperature of the receiving water body, and (2) by entrainment and impingement of aquatic organisms. A concept for an NEC once-through cooling system is proposed that would minimize these impacts by utilizing deeper offshore waters than have been used heretofore for coastal plants.

A concept for the design of an offshore heat dissipation system is shown in Fig. 1 ( $p .8$ ). I'he intakes are located sufficiently far from shore to avoid the shallow-water in-shore areas which are characterized by higher biological productivity than the offshore areas which are generally less productive. The discharge is a tandem jet diffuser, with high-velocity jets for good mixing of the discharge with ambient water. The jets are oriented in the offshore direction, so that the resulting plume would have a considerable offshore momentum which tends to carry the plume seaward during periods of low ambient currents. The intake and discharge are connected to a pumphouse on shore via underground water conduits which may be either tunnels or buried pipeline. The NEC itself is set back some distance from the shoreline, so that recreational use of the shoreline is not impeded.

A heat dissipation system design already developed for a power station can be scaled-up to the size required for an NEC module, using scaling laws based on Froude similitude. As an example, the design 
for the two-unit San Onofre units 2 and 3 station was scaled-up to the capacity for an 8-unit NEC module. Assuming the same temperature rise $(\Delta \mathrm{T})$ and number of jets, the NEC module diffuser would have the first part in $16 \mathrm{~m}$ water depth, and would extend $2650 \mathrm{~m}$ in length, compared with $9 \mathrm{~m}$ water depth and $1520 \mathrm{~m}$ length for the San Onofre design. The resulting plume would have the same temperature distribution, but the area within each isotherm would be 3.03 times greater for the NEC module, and the jet discharge velocity would be 1.32 times greater. This analysis shows that an NEC module design of reasonable dimensions could produce a plume with reasonable surface temperatures and areas within isotherms. The results are based on hydraulic and analytical modeling, since no thermal diffusers of the proposed design are presently in operation.

The environmental effects of the heat dissipation system may be divided into the effects of an increase in the temperature of the receiving water, and all other effects on aquatic life.

The undesirable effects of heat, such as heat stress and possible cold shock, are largely avoided by the rapid mixing of the discharge with ambient water in the jet diffuser (Sect. 3.0). The resulting mixed plume is only 1 to $2^{\circ} \mathrm{C}$ above ambient temperature, and is within the natural range of coastal water temperature changes caused by changing winds and tides (Sect. 2.0). The indirect effects of a warm plume are not well understood, but may include effects on fish migration and spawning at some sites. There is some consensus among aquatic ecologists that the warming of colder waters often rcsults in an increase in biological productivity.

The most important and ecologically significant effects on aquatic biota are caused by entrainment of plankton and fish eggs and larvae (ichthyoplankton) and impingement of small fish too large to pass through the intake screens of power plants. At present, there is not sufficient data to determine the effects of fish losses due to these causes on fish population dynamics. However, a conservative estimate of fish losses due to an 8-unit module, not including any compensating effects on population dynamics, for a middle-Atlantic region, was slightly under $1 \%$ of the annual commercial catch for the region (Sect, 5.3).

The monitoring of relative numbers of fish is required in the vicinity of NRC-licensed plants. The data normally obtained in routine monitoring 
are not sufficient nor adequate to determine effects of plant impacts on population dynamics. Some useful data have been obtained from San Onofre unit 1. These data show that about the same number of species of fish are found near the plant discharge as in a control area about $8 \mathrm{~km}$ downcoast, and that more fish are found near the discharge than in the control area, over the greater part of the year (Sect. 5.3).

The cost of an offshore system would be highly site-dependent, and would depend on the length of conduits required to reach sufficiently deep water, and the type of rock or soil at the site. By comparison with existing designs, it was estimated that a once-through NEC module at a fayorable sitè would cost less, but not greatly less, than a closed-cycle system. A once-through system may be preferred for some sites even without a direct cost advantage, because of advantages such as lower atmospheric and visual impacts, and a possible reduction in site land area requirements (Sect. 6.0).

For water condults, in favorable rock, experience indicates that tunneling would be cheaper than buried pipeline by about the cost of installation of pipeline. However, unfavorable conditions, such as hard rock or fractured or nonsupporting rock, can increase the cost of tunneling by factors of two or three. Tunneling has the advantage that the land surface need not be disturbed except for test borings.

\section{CONCLUSIONS}

1. The heat from an NEC can be adequately dispersed by use of a submerged jet diffuser only moderately larger and located in moderately deeper water than diffusers designed for present-generation power stations. A diffuser of the type proposed is not presently in commercial operation,

2. The NEC offshore heat dissipation system concept appears to be economically competitive with closed-cycle systems. However. the costs of offshore systems are highly site-dependent.

3. Once-through systems have several advantages over closed-cycle systems:

- Atmospheric and visual impacts can be practically eliminated.

- High thermal efficiency and negligible loss of sumer peak capacity are obtained.

- The land area required for the NEC may be substantially smaller. 
4. Once-through systems have the disadvantage of greater impact on the aquatic environment.

- Under some conditions, a large volume of warm water (only slightly above ambient temperature) can accumulate in the vicinity of the discharge. The ecological effects of slightly warm plumes are not well understood. However, the overall effect is not necessarily detrimental, particularly in colder waters.

- Entrainment and impingement could reduce the populations of various aquatic species and affect the structure and function of the aquatic ecosystem. The most important impacts might be on some species of fish. The prediction of these impacts on fish population dynamics is not presently within the state of the art. A prediction based on conservative assumptions indicates that the effect of an 8-unit NEC module on important fish species populations would be about two orders of magnitude less than the known impact of commercial fishing. The NEC offshore concept is expected to minimize the effects of entrainment and impingement by locating the intakes in relatively deep water where the concentration of aquatic life is relatively low.

5. In site selection for a coastal NEC, a site underlain by rock favorable for the construction of water tunnels is to be preferred. Tunnels do not disturb the land surface nor the shoreline and are eronmir in favnrahle rock. However, buried pipelines are also feasible and can be readily emplaced on sites underlain by unconsolidated sediments. 


\section{ACKNOWLEDGMENTS}

The author gratefully acknowledges the assistance of Oak Ridge National Laboratory members S. Marshall Adams, for his helpful review of the section on aquatic environmental effects, and Millard L. Myers, for his compilation of information on construction of underground water conduits. 
Fig. 1 A conceptual design for a submerged offshore heat dissipation system for an NEC. . . . . . . . . . 8

Fig. 2 Offshore heat dissipation system designed for San Onofre Nuclear Generating Station Units 2 and 3. . . . . . . . 14

Fig. 3 Kilometer scale appropriate for 8-unit NEC module superimposed on San Onofre model isotherm plot (from Fig. 6.44, Ref. 10). ................... . . . . . . . . .

\section{LIST OF TABLES}

Table 1 Summer water temperatures at typical locations on the U.S. coasts and the Great Lakes. . . . . . . . . . . 3

Table 2 Hydraulic scaling laws. . . . . . . . . . . . . . 13

Table 3 Diffuser scale-up to NEC size. . . . . . . . . . . 16

Table 4 Fish collected in bottom nets at San Onofre unit 1 in 1975. . . . . . . . . . . . . . . . . . . 21

Table 5 Characteristics of several designs for offshore heat dissipation systems. . . . . . . . . . . . . .23 
OFFSHORE HEAT DISSIPATION FOR NUCLEAR ENERGY CENTERS

Howard F. Bauman

\begin{abstract}
The technical, environmental, and economic aspects of utilizing the ocean or other large water bodies for the dissipation of reject heat from Nuclear Energy Centers (NECs) were investigated. An NEC in concept is an aggregate of nuclear power plants of $10 \mathrm{GW}(e)$ capacity or greater on a common site. The use of once-through cooling for large power installations offers advantages including higher thermal efficiencies, especially under summer peak-load conditions, compared to closed-cycle cooling systems. A disadvantage of once-through cooling is the potential for greater adverse impacts on the aquatic environment. A concept is presented for minimizing the impacts of such systems by placing water intake and discharge locations relatively distant from shore in deeper water than has heretofore been the practice. This technique would avoid impacts on relatively biologically productive and ecologically sensitive shallow inshore areas. The NEC itself would be set back from the shoreline so that recreational use of the shore area would not be impaired. The characteristics of a heat-dissipation system of the size required for a NEC were predicted from the known characteristics of a smaller system by applying hydraulic scaling laws. The results showed that adequate heat dissipation can be obtained from NEC-sized systems located in water of appropriate depth.
\end{abstract}

Offshore intake and discharge structures would be connected to the NEC pump house on shore via tunnel.s or buried pipelines. Tunnels have the advantage that shoreline and beach areas would not be disturbed. The cost of an offshore heat-dissipation system depends on the characteristics of the site, particularly the distance to suitably deep water and the type of soil or rock in which water conduits would be constructed. For a favorable site, the cost of an offshore system is estimated to be less than the cost of a closed-cycle system.

\title{
1. INTRODUCTION
}

The Nuclear Energy Center (NEC) is a concept for siting a large number of nuclear power plants at the same location. ${ }^{1,2}$ It would have a capacity of greater than $10 \mathrm{GW}(\mathrm{e})$, and would therefore require that more than $20 \mathrm{GW}(\mathrm{th})$ of low-grade heat be dissipated to the environment. Since most lakes and rivers do not have sufficient heat capacity to absorb this 
large quantity of heat, the NEC studies to date have proposed that the heat be dissipated by evaporative cooling, typically in cooling towers. The various effects of dissipating this large amount of heat in the atmosphere have been considered and are the subject of continuing study, e.g., the METER program. ${ }^{3}$

On the other hand, very large bodies of water, mainly the oceans and the Great Lakes, may be considered infinite heat sinks even for the large quantities of heat that would be discharged from an NEC, and could be used for once-through cooling. The technical, economic, and environmental considerations of once-through cooling for NECs are the subject of this report.

\section{ADVANTAGES AND IMPACTS OF ONCE-THROUGH COOLING}

Once-through cooling affords a significant conservation advantage in that higher thermal efficiencies are obtained. Further, since relatively cool water is available from large water bodies even in summer, there is little or no loss of summer peak generating capacity due to high condenser temperatures in hot weather. This is a significant advantage for the majority of U.S. utilities that experience a summer load peak.

\subsection{Water Temperatures}

The temperature of water available at moderate depths in large water bodies is significantly lower than the usual design water temperature of closed-cycle systems. A typical design water temperature for a wet cooling tower system is about $32^{\circ} \mathrm{C}$. For economic reasons, most systems are designed to meet the design conditions about $95 \%$ of operating time, so that in hot humid weather (i.e., about $5 \%$ of operating hours) the condenser cooling water temperature generally exceeds $32^{\circ} \mathrm{C}$.

Some summer water temperatures, at the surface and at moderate depths, for typical locations on the U.S. coasts and Great Lakes, are given in Table 1. These data, taken from various power plant environmental statements, are daily average maximum summer water temperatures or closely similar measurements. Cool water is available in summer on the Pacific coast, the northern Atlantic coast, and on the Great Lakes. The waters of 
Table 1. Summer water temperatures at typical locations on the U.S. coasts and the Great Lakes

\begin{tabular}{|c|c|c|c|c|}
\hline \multirow{2}{*}{ Location } & \multirow{2}{*}{$\begin{array}{l}\text { Distance } \\
\text { offshore } \\
\quad(\mathrm{m})\end{array}$} & \multicolumn{2}{|c|}{$\begin{array}{l}\text { Summer water temperature } \\
\left({ }^{\circ} \mathrm{C}\right)\end{array}$} & \multirow{2}{*}{$\begin{array}{l}\text { Water deptha } \\
\text { (m) }\end{array}$} \\
\hline & & Surface & Subsurface & \\
\hline Seabrook, NH & 1600 & 19 & 11 & 15 \\
\hline Atlantic, $\mathrm{NJ}$ & 6000 & 24 & 21 & 10 \\
\hline \multicolumn{5}{|l|}{ North Carolina } \\
\hline $\begin{array}{l}\text { North of } \\
\text { Hatteras }\end{array}$ & Nearshore & 26 & 25 & $\mathrm{NA}^{\mathrm{b}}$ \\
\hline $\begin{array}{l}\text { South of } \\
\text { Hatteras }\end{array}$ & Nearshore & 28 & 26 & NA \\
\hline Pompano, FL & 3000 & 30 & 28 & 30 \\
\hline Texas, Gulfcoast & NA & 30 & 24 & 30 \\
\hline San Onofre, CA & 3000 & 22 & 20 & 10 \\
\hline Lake Erie & NA & 23 & 11 & 25 \\
\hline Lake Ontario & NA & 22 & 17 & 30 \\
\hline
\end{tabular}

${ }^{a}$ Depth at which temperature was measured.

${ }^{\mathrm{NA}}$; data not available. 
the south Atlantic and Gulf coasts are warmer, but still cool relative to typical closed-cycle system water temperatures. Most of the water bodies are stratified to some extent in summer, that is, the surface layers are warmer than deeper layers. Except for the southern Atlantic coasts, where strong currents keep the waters over the continental shelf well mixed, the water available at moderate depths is significantly cooler than the surface water for most summer conditions.

Natural fluctuations in water temperature on the order of $5^{\circ} \mathrm{C}$ over short time spans (days or hours) are common at most locations. These fluctuations are caused by movements of water masses of differing temperatures. Common examples include upwelling of cold bottom water by winddriven currents, and the tidal movement of solar-heated water from shallow areas. The temperature difference of a well-mixed plume from a oncethrough cooling system (over the ambient water temperature) should be less than the short-term natural fluctuations in water temperature observed in large water bodies.

\subsection{Atmospheric Effects}

For an NEC, the most significant advantage of once-through cooling may prove to be the avoidance of the problems of atmospheric heat dissipation. It has been postulated that a large source of atmospheric heat and moisture might trigger precipitation, thunderstorms and other atmospheric phenomena, but the extent to which this might occur is presently not known. In the NECSS-75 study, ${ }^{1}$ it was assumed that groups of plants would be widely separated $[2.5$ miles $(4 \mathrm{~km})$ between groups of four] to avoid possible atmospheric effects. If such large spacing is indeed found to be necessary with evaporative cooling, an NEC employing once-through cooling would have the advantage of requiring a much smaller land area.

\section{2,3. Environmental Acceptance}

The main environmental impacts of once-through cooling are effects on ecosystem structure and function due to an increase in water temperature and due to entrainment and impingement of aquatic organisms. A once-through cooling system to be environmentally acceptable must be sited, designed, and operated to minimize these impacts. To meet environmental regulations it 
must qualify for a FWPCA Section 316 exception, which requires that a balanced indigenous population of aquatic life be maintained.

\section{DESIGN CONSIDERATIONS FOR AN OFFSHORE HEAT DISSIPATION SYSTEM}

Nearly all of the coastal power plants (nuclear and fossil) now operating use once-through cooling with shoreline intake and discharge systems. These systems have the environmental disadvantages of disturbing the shoreline and of withdrawing and discharging water from relatively shallow areas where heat dissipation is hindered and where biological productivity tends to be relatively high. Several new plants, such as Seabrook, NH, and San Onofre, CA (units 2 and 3), have been designed with submerged offshore heat dissipation systems to minimize impacts on the aquatic environment. ${ }^{4,5}$ The considerations presented here for an offshore heat dissipation system for an NEC are based on recent studies in thermal hydraulics and aquatic ecology performed for various coastal power plants including those just mentioned and the offshore floatingi nuclear plants (Atlantic, $\mathrm{NJ}$ ). 6,7

Excessive temperatures in the receiving water body can be avoided by discharging the condenser effluent through a jet or jet diffuser system in sufficiently deep and open water. The jets entrain cool bottom water so that the heated discharge is diluted rapidly by a factor of about 8 to 10 . The mixed plume is then at most only $1^{\circ} \mathrm{C}$ or $2^{\circ} \mathrm{C}$ above ambient and drifts along the surface until it is dissipated. The diluted plume at this moderate temperature would not cause damage to aquatic life from either excessive temperatures or from "cold shock" (the sudden withdrawal of the heat source). Under some conditions large volumes of slightly warmed water $\left(1^{\circ} \mathrm{C}\right.$ or less above ambient) can accumulate near a discharge. The ecological effects of such warming are as yet not well understood. Some ecologists believe that the principle effect of warming in cold waters is to enhance biological productivity (refer to sect. 5.2). Under some conditions, when the surface waters are stratified and appreciably warmer than the bottom waters, the temperature of the mixed plume from a submerged discharge may be no greater than or even less than the ambient surface temperature. 
In recent studies, problems other than water temperature, particularly impingement and entrainment, have drawn increasing attention.

Impingement is mainly the trapping of small fish too large to pass through the openings of the intake screens of a water intake system. Large fish and most pelagic fish generally swim fast enough to escape impingement. A number of measures have been tried to reduce impingement, but the most effective may be to locate the intake where concentrations of small fish are relatively low. In general, the deeper the water and the further from shore, the less the impingement probability.

Entrainment is the drawing in of organisms (plankton) too small to be caught on the intake screens. Eggs and larva of fish are planktonic and their entrainment could adversely affect fish populations. Intakes, therefore, should be located away from spawning and nursery areas, in order to reduce the probability of adverse impacts. Once again, locations in deeper water further from shore are generally most favorable.

Generally some fraction of entrained organisms survive passage through a once-through cooling system. A major stress on the organisms is the increase in water temperature $(\Delta \mathrm{T})$ in the condenser; the time at elevated. temperature before being returned to cooler water is a major factor in survival. For a given rate of heat removal, the water flow required is inversely proportional to the $\Delta T$. This leads to a tradeoff in the design of a once-through cooling systems; lower water flow at higher $\Delta T$ reduces the amount of impingement and entrainment, but increases the thermal stress on those organisms that are entrained. A complete analysis of this question (which is the subject of continuing study ${ }^{8}$ ) is beyond the scope of this report, but the following points are relevant:

- The economics of offshore cooling favor lower flow at higher $\Delta T$. This reduces the size of the conduits and reduces the pumping power required.

- Plankton populations other than ichthyoplankton are usually in a dynamic equilibrium at a level determined by availability of food and nutrients. In this situation, plankton which fail to survive passage through a cooling system would be rapidly replaced through normal reproduction. Any loss of ichthyoplankton is not immediately recovered, but fish populations also tend to be in a dynamic 
equilibrium, so that loss of ichthyoplankton would not necessarily result in a significant reduction of the adult fish population.

- Both surviving and non-surviving plankton are returned to the ocean and are not lost to the aquatic food chains.

The above considerations would support the conclusion that a high survival rate of plankton entrained in a cooling system is not necessarily required for the maintenance of a balanced indigenous aquatic population.

Very little is known about the ecological and economic implications of the impacts incurred from once-through systems. It seems logical that the population and productivity of species that are affected by entrainment or impingement could become depressed in the vicinity of a oncethrough system. For wide-ranging species this might result in a very slight depression over a very large region (and would probably be practically impossible to measure). For species that do not range widely, there might be a noticeable depression locally while other parts of the region would be unaffected.

Ecologists have not reached agreement as to which of the various kinds of unavoidable adverse impacts from human activities should be concentrated in a few locations and which should be distributed as broadly and evenly as possible. Obviously, the pursuit of the NEC concept leads to the concentration of impacts in a few locations. For the case of aquatic entrainment and impingement, concentration may be an advantage because any local depression in the number of entrainable organisms would correspondingly reduce the number of organisms subsequently entrained. In compensation, other parts of the region would remain undisturbed and could supply reproductive capacity for entrainment-affected organisms in order to maintain a "balanced indigenous population" for the region as a whole.

\section{CONCEPT FOR AN OFFSHORE HEAT DISSIPATION SYSTEM}

A concept for a once-through cooling system for an NEC is presented to illustrate the features that could make such a system environmentally attractive. The system consists of submerged intake structures and tandem jet diffusers connected to the NEC by tunnels or underwater pipelines as shown in Fig. 1. The system shown is a module to serve eight $1200 \mathrm{MW}(\mathrm{e})$ 


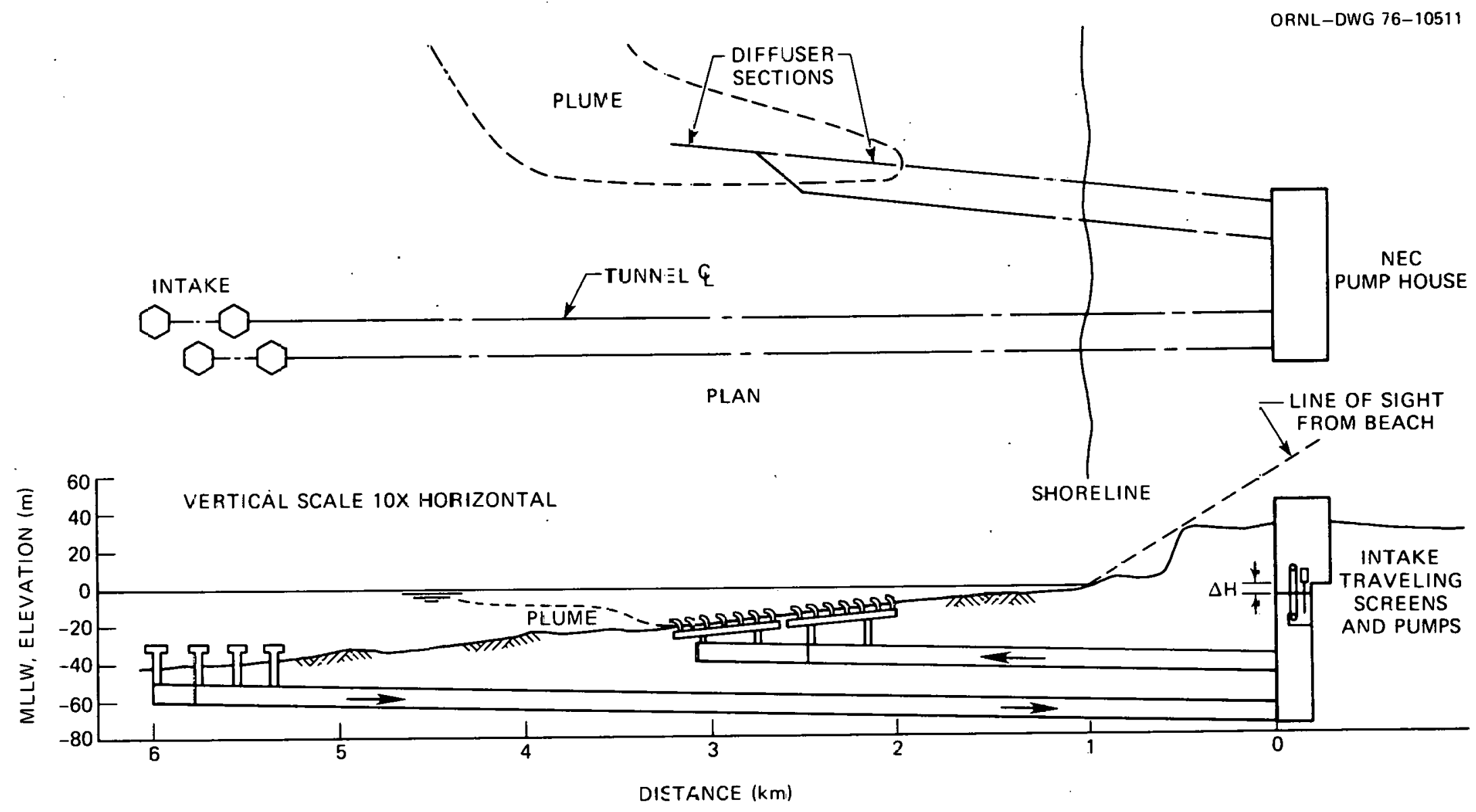

Fig. 1. A conceptual ćєsign for a submerged offshore heat dissipation system for an NEC. 
units, which would be set back about $1 \mathrm{~km}$ from the shore. As construction of the NEC proceeded beyond eight units, another similar offshore module would be constructed several kilometers distant along the shore. The exact sizes, numbers of components, layouts, and distances are not critical to the concept and are intended to be illustrative.

\subsection{Intake}

The design and location of the intake structures may be the most important element in the acceptability of once-through systems for NECs, because of the ecological importance of impingement and entrainment. In this concept, the intakes are located as far as necessary offshore to reach relatively deep water. While the exact location and depth of the intakes would be strongly influenced by site conditions, an intake depth of 30 meters appears to be a reasonable goal for many sites. The intake structures are covered with "velocity caps" to reduce impingement, and the openings are positioned about one-third the water depth above the bottom to reduce impacts on bottom-dwelling fish. A velocity cap covers the top of an intake, so that water enters from the side. It has been shown that fish more readily sense and avoid a horizontal flow acceleration at a side intake than a vertical acceleration at a top inlet. The intakes are clustered so that the predatory effect of the intake is concentrated at one location. (If the intake should depress certain aquatic populations in the vicinity of the intake, it would be an advantage to take all of the required water from the point at which the population was already depressed.) Furthermore, clustering leaves the maximum area of ocean habitat completely undisturbed.

\subsection{Diffusers}

Multiple-jet tandem diffusers are located inshore of the intakes. The jets are oriented in the offshore direction, and the momentum of the discharge would move the plume away from shore during periods of low ambient currents. The inshore end of the diffuser is in water sufficiently deep (about $10 \mathrm{~m}$ ) to provide ample inflow of dilution water. Under certain current conditions, the diluted plume may pass over the intake structures, but thermal stratification is expected to minimize recirculation of warmed water. The tandem jet design was adapted from a design proposed for the 
Perry, Ohio, nuclear station and tested in a hydraulic model. ${ }^{9}$ The design allows free access for dilution water from the sides of the diffuser to mix with each jet under various ambient flow conditions. Under the condition of strong along-shore current, model studies show that a broad, well-mixed plume streams off the lee side of the diffuser. Under the condition of low ambient current, each jet reinforces the offshore movement of the plume, so that the entire plume streams off the end of the diffuser in the offshore direction. Good dispersion of the heated effluent was demonstrated under all flow conditions tested.

\subsection{Puimphouse}

A pumphouse containing coventional intake screens is located onshore, from which cooling water is distributed to the power plants to be served. The pumphouse and the NEC controlled area are set back from the shoreline about $1 \mathrm{~km}$, and the reactor buildings are set back somewhat further within the usual exclusion area. For a typical coastal topography, the buildings would be below the line of sight from the beach (as shown on Fig. 1), and the NEC would not interfere with any of the usual recreational uses of the shoreline.

\subsection{Plant Layout}

The layout of plants within the NEC is not critical to the concept. Economics of cooling water distribution would favor relatively short distances between the pumphouse and the power plants. Either surface canals or underground conduits could be used to distribute the cooling water, depending on site conditions. A possible arrangement for eight plants served from a pumphouse module could be two groups of four plants each (quads) separated by a distance of about $I \mathrm{~km}$ and set back about $1 \mathrm{~km}$ from the boundary of the controlled area.

\section{ENVIRONMENTAL EFTECTS}

\subsection{Impacts of Construction}

The impacts of construction of the proposed NEC offshore heat dissipation system depend largely on the type of water conduit used. 
Where tunneling is feasible, there is almost no impact on the shoreline, and only small areas of ocean bottom are disturbed around the intake and diffuser structures.

Where pipeline is installed, a corridor across the shoreline and along the ocean bottom will be disturbed for a period of two to three years. It is anticipated that the shoreline would be restored to approximately its original condition, and that the disturbance of the ocean bottom (e.g., displacement of benthic organisms) would heal naturally in a few years. Shoreline restoration is practical in most locations, but could be very difficult in ecologically sensitive areas such as marshes or mangrove swamps. Hopefully, sensitive areas could be avoided in the site-selection process.

All in all, the impacts of construction would be temporary and nonrepetitive, and would not be expected to have long-term effects on the ecosystem. An excellent discussion of the impacts of along shore construction, including the effects of dredging, may be found in Ref. 10 .

\subsection{Physical Effects of Operation}

The possible physical effects of a once-through heat dissipation system can include bottom scouring, sediment deposition, interference with littoral sediment transport, and the formation of a heated-water zone or thermal plume. An offshore system by nature avoids interference with littoral transport, and can be readily designed to avoid scouring or sediment deposition. The only important physical effects expected are associated with the thermal plume.

The characteristics of a submerged jet discharge are rapid mixing of the heated discharge with ambient water to produce a mixed plume generally less than $2^{\circ} \mathrm{C}$ above ambient water temperature. Under these conditions, only a small fraction of the heat (less than $5 \%$ ) is immediately transferred to the atmosphere; and atmospheric effects, which may include occastonal "steam fog," are generally negligible. On a longer time scale the water body, which is in a dynamic equilibrium with the atmosphere, will transfer any excess heat to the atmosphere by evaporation, conduction and radiation. This eventual transfer of heat to the atmosphere occurs over a large surface 
at an energy density which is small compared to natural processes, and is therefore not expected to trigger atmospheric effects.

Analysis of a Thermal Plume. A thermal plume is generally characterized by the surface area and/or volume within isotherms above ambient temperature. Methods are available for predicting the extent of a thermal plume for specific cases, given specifically the design of the diffuser, the bottom topography, and the temperature and current regime of the ambient waters. Design studies could typically include the construction of a hydraulic model as well as the use of computer models. Since efforts of this magnitude are hardly justified for a hypothetical system, a simpler approach has been taken for this analysis. The characteristics of a typical NEC once-through heat dissipation system will be predicted by scaling up a study made for an actual system, using the hydraulic scaling laws based on Froude similitude, as shown in Table 2. We would have preferred to scale-up field data rather than hydraulic model data, but as yet there is not a diffuser of the proposed type in operation. There is, of course, a larger degree of uncertainty in scaling up model data that has not been subject to field verification. However, it is likely that appropriate field data will become available within the next few years, in time to be useful in the design of diffusers for the first generation of nuclear energy centers.

The heat dissipation system designed for San Onofre, units 2 and 3, (Fig. 2) is very similar to the conceptual design proposed here for an NEC. The major difference is in the orientation of the jets; in the NEC conceptual design all jets are oriented directly seaward; in the San onofre design alternate jets are oriented $20^{\circ}$ to either side of the seaward direction. (For low ambient currents, the San Onofre design would produce a wider plume, and the NEC design a narrower plume with greater offshore momentum.)

The San Onofre design was tested under a variety of ambient flow conditions in a hydraulic model. ${ }^{10}$ In this analysis we will apply the results of the model test to an assumed prototype with a discharge four times greater than that of San Onofre, representing an eight-unit prototype NEC heat dissipation module. The dimensions of an NEC prototype scaled up in this fashion, compared with the dimensions of the San Onofre prototype, are 
Table 2. Hydraulic scaling laws

\begin{tabular}{lc}
\hline Quantity & $\begin{array}{c}\text { Scale ratio } \\
\text { prototype to } \\
\text { model }\end{array}$ \\
\hline Temperature difference & 1.0 \\
Length & $\ell^{a}$ \\
Velocity & $\ell^{1 / 2}$ \\
Time & $e^{1 / 2}$ \\
Flow & $\ell^{5 / 2}$ \\
\hline
\end{tabular}

Wherel is the ratio of prototype length to model length for an undistorted model. 
ORNL-DWG 78-16820
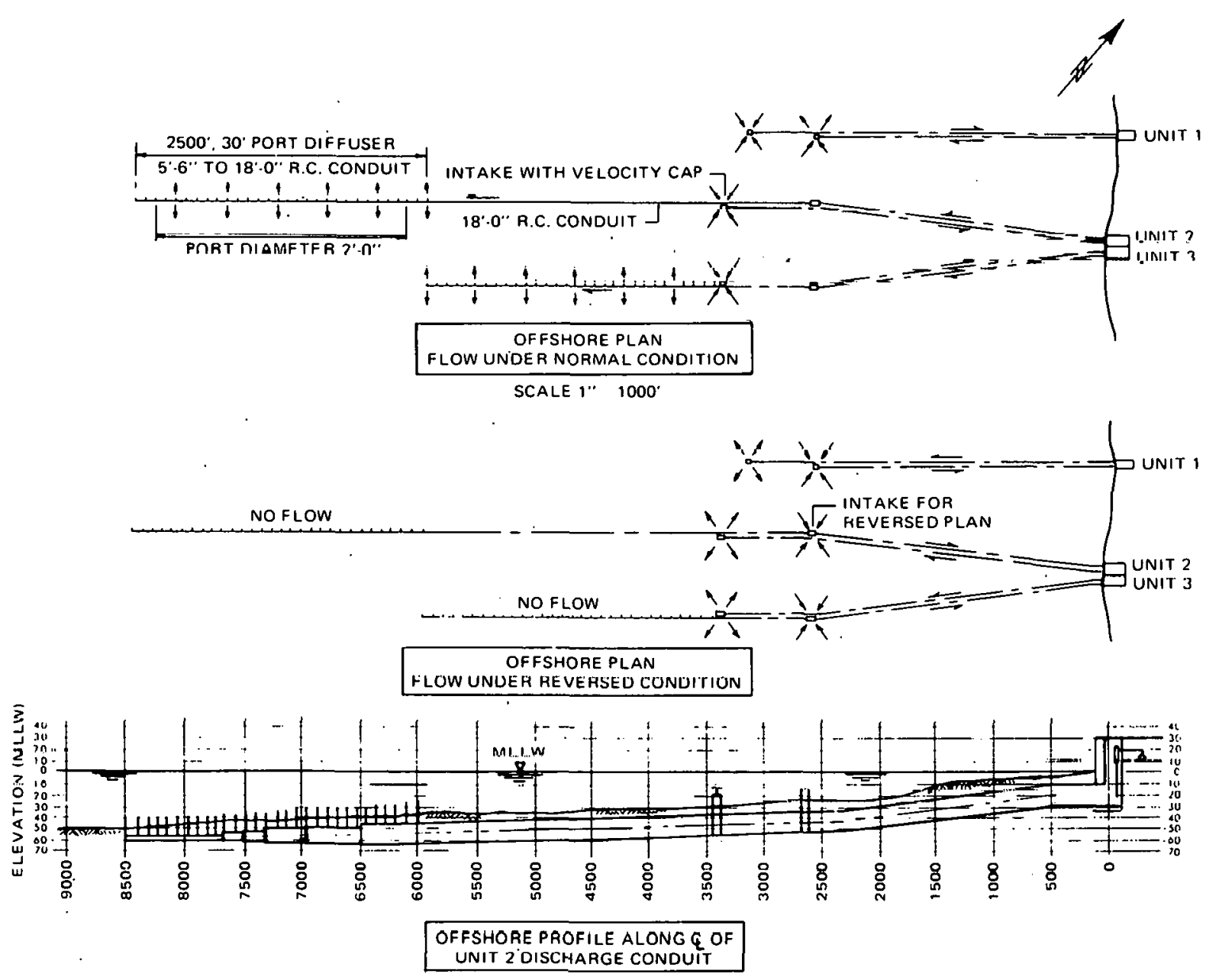

F1g. 2. Offshore heat dissipation system designed for San Onofre Nuclear Generating Station Units 2 and 3. 
given in Table 3. Note that in this method of scale-up, the flow is scaled up directly, the $\Delta T$ is unchanged, and the number of jets are unchanged. For a flow scale-up of four, the linear dimensions increase by a factor of 1.74, area by 3.03 , and the jet velocity by 1.32 . The results (isotherm plots) obtained for the San Onofre cases may now be applied to the NEC prototype by applying the same factors (e.g., multiplying linear dimensions by 1.74$)$.

A typical isotherm plot scaled up for the NEC 8-unit prototype is shown in Fig. 3. The plume temperature is above ambient by no more than $10 \%$ of the system temperature rise $(\Delta \mathrm{T})$, indicating a jet dilution of greater than 10 in the mixing zone. The area within each isotherm is a factor of 3.03 greater than the comparable area for a two-unit station. The above analysis was carried out to show that a reasonable heat dissipation system design for an 8-unit module could produce reasonable plume temperatures and areas within isotherms. While it is instructive to see how an established design for a diffuser can be scaled up to the size required for an NEC, the design of large diffusers for an NEC is of course not limited to the scale-up of previous designs.

\subsection{Effects of Operation on Aquatic Biota}

The Nuclear Regulatory Commission has recently published the Environmental Statement related to the manufacture of Floating Nuclear Power Plants (FNP) by offshore Power Systems. ${ }^{6}$ This document includes, in addition to a description of the aquatic ecology of the Atlantic and Gulf Coasts, a comprehensive assessment of the effects of once-through heat-dissipation systems on aquatic biota. Several findings from this study are relevant to the NEC system concept.

Ecological effects are caused by entrainment, impingement, chemical and biocide discharges, and temperature changes.

The populations of the simpler life forms are not believed to be sensitive to entrainment losses. Because of their short life cycles, losses are compensated for by rapid reproduction. The analysis of entrainment effects was concentrated on ichthyoplankton, since fish populations are believed to be most sensitive to entrainment losses. The larvae of many species remain in sheltered waters and would not be subject to entrainment 
Table 3. Diffuser scale-up to NEC size

\begin{tabular}{lrrr}
\hline & $\begin{array}{r}\text { San Onofre, } \\
2 \text { units }\end{array}$ & $\begin{array}{r}\text { NEC, } \\
8 \text { units }\end{array}$ & Ratio \\
\hline Flow, ${ }^{3}$ /s & 105 & 420 & 4 \\
Temperature rise, ${ }^{\circ} \mathrm{C}$ & 11 & 11 & 1 \\
Number of diffusers & 2 & 2 & 1 \\
Number of ports per diffuser & 63 & 63 & 1 \\
Port diameter, m & 0.52 & 0.90 & 1.74 \\
Port area, m & 0.21 & 0.64 & 3.03 \\
Discharge velocity, m/s & 3.94 & 5.21 & 1.32 \\
Distance from shore, m & & & 1.74 \\
$\quad$ Diffuser 1, first port & 1067 & 1860 & 1.74 \\
Diffuser 2, first port & 1524 & 2650 & 1.74 \\
Diffuser 2, last port & 2590 & 4510 & 1.74 \\
Water depth, m & & & 1.74 \\
Diffuser 1, first port & 9.1 & 16 & 29 \\
Diffuser 2, last port & 16.8 & & \\
\hline
\end{tabular}




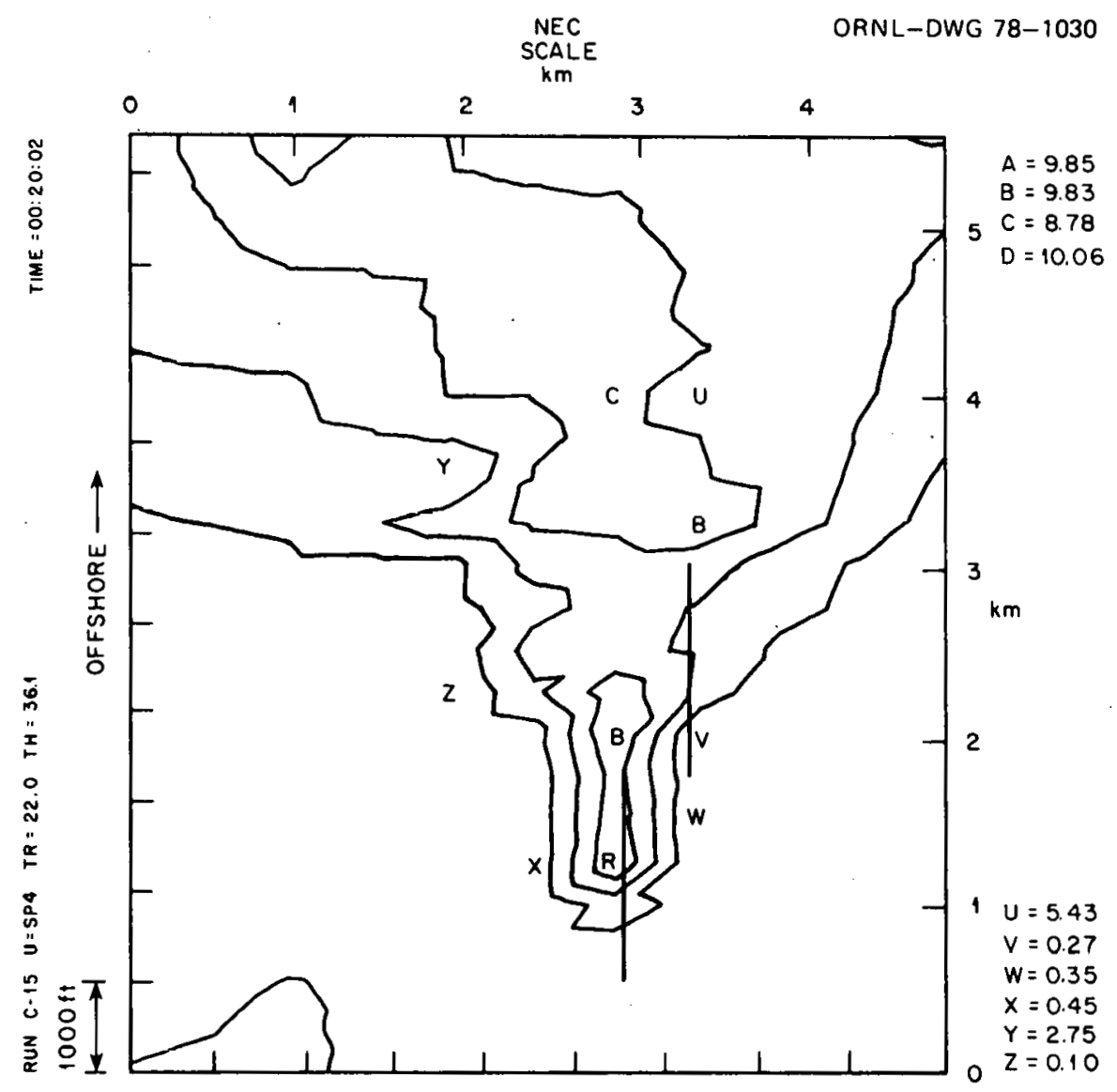

Fig. 3. Kilometer scale appropriate for 8-unit NEC module superimposed on San Onofre model isotherm plot (from Fig. 6.44, Ref. 10). Surface isotherms (in increments of $2.5 \%$ of source $\Delta T_{0}$ ) for speclal current sequence SP4. (Diffusers shown as straight 11nes; Instantaneous current speed $=0.0$ knots.) 
at an offshore intake. The larvae of several common species are found in open waters and would be subject to entrainment. The potential changes in fish populations due to entrainment of eggs and larvae cannot be quantified because the requisite data on population dynamics are not known. However, for the FNP study the loss of $f$ ish due to entrainment was estimated based on conservative assumptions and this loss compared with the commercial fish catch for each of five coastal regions. Based on this data, the annual loss of fish (0-1 year class) due to entrainment in an 8-unit NEC module for the middle Atlantic region would be from $0.2 \%$ to $0.8 \%$ of the commercial catch. These data are based on conservative estimates of larval densities and do not take into account any compensating mechanisms in the population such as density dependence.

Another approach to estimating the effect of entrainment is to evaluate the volumes of water involved. The intake for an 8-unit module. drawing from an average $30 \mathrm{~m}$ deep bottom layer daily draws in the volume of water within a circle of about $600 \mathrm{~m}$ radius. This is a very small fraction of the water over the continental shelf off the coast of a region served by an NEC. The overall effect of the module would be to "thin out" the planktonic biota in the plume streaming from the vicinity of the diftuser; for a typical dilution ratio of 10 to 1 , and conservatively assuming zero survival, the density of live planktonic biota in the plume would be about $90 \%$ of that in the ambient waters. The $108 s$ to the ecosystem is small on a regional scale and would not be expected to disturb the structural and functional characteristics of biotic populations in the vicinity of the discharge. However, some increase in the abundance of organisms which feed on detritus would be expected.

Impingement of fishes on intake screens is readily observed and measured in operating plants, but its effect on fishery populations is very difficult to quantify and predict. The FNP statement concludes that small schooling fishes may be an intermittent problem for offshore intakes, but that the fraction of fish taken is not likely to be large enough to disturb the population balance. The best defense against impingement is the siting of intakes away from locations where small schooling fishes are prevalent. 
The principle chemical and biocide discharges from a once-through system are copper, nickel, and chlorine. Copper and nickel may be present as corrosion products from heat exchanger surfaces; the FNP statement concludes that the probable concentrations would not be large compared to the natural concentrations in seawater, and that toxic effects are not expected. Chlorine treatment is a commonly used procedure to prevent biological fouling of the heat exchange surfaces; a typical schedule is two hours of chlorination per day. Entrained organisms do not survive chlorination. The FNP statement recommends that treatment be controlled to limit the residual chlorine in the discharge to less than $0.1 \mathrm{mg} / 1 \mathrm{iter}$. Under these conditions essentially no residual chlorine appears in the plume, because it is consumed by the chlorine demand of the dilution water entering the discharge jets.

In addition to chlorination, the temperature of the intake and discharge conduits is generally increased periodically to remove organisms which would otherwise encrust exposed surfaces. Entrained organisms do not survive heat treatments. Heat treatment has been shown to not appreciably increase the overall impact of a heat dissipation system. ${ }^{11}$

Direct temperature effects are minimal for systems employing submerged jet diffusers, because the discharge is rapidly diluted with ambient water. The only high temperature portions of the discharge are within the high velocity regions of the jets, where fish are not expected to reside. The temperature of the mixed plume is generally less than $2{ }^{\circ} \mathrm{C}$ above ambient. This temperature increase is of the same order as natural temperature changes that can be observed in the coastal ocean over periods of a few hours as winds and tides change (Sect. 2.0). Bottom temperatures are usually unaffected outside the mixing zone of the jets, because the warm plume is buoyant and remains on the surface.

Indirect effects of temperature are more difficult to assess. Fish are known to exhibit temperature preference and probably grow faster within their preferred temperature range (which differs by species). Thus, fish often seek a thermal plume in cold waters and avoid a plume in waters warmer than their preferred temperature. Migrating fish may linger in a warm plume. Water temperature is known to affect spawning. Effects on migration and spawning may be important for some sites, but at present 
no satisfactory data are known for offshore locations. The overall effects of the warming of water by an NEC are expected to be small because the temperature of the mixed plume is only slightly above ambient, and because the area affected is small compared to the total water area of a coastal region.

Field Studies. Although shoreline once-through systems have been used for many years, there is very little experience with offshore systems. There is at present no data from which the effects of offshore systems on the population dynamics of aquatic biota can be evaluated. Certain routine monitoring of aquatic populations is required for NRC-1icensed plants, but the scope of routine environmental monitoring is not broad enough to permit analysis of population dynamics.

Aquatic monitoring data have been obtained from San Onofre unit one. Much of these data are summarized and analyzed in an NRC report by Adams et al. ${ }^{12}$ The 1975 fish collection data were singled out for analysis. Bottom nets were placed at 9-m depth near the outfall, and similar sampling was conducted simultaneously at control stations about 8-km downcoast during all four seasons of the year. A summary of the results is given in Table 4. The results show that the number of species is about the same in both the discharge and the contol areas, and that, for three of the four sampling periods, more fish were found near the discharge than in the control area. Some preoperational fish sampling had been done at San Onofre, but the data were not considered sufficient for a meaningful comparison of preoperational and operational fish populations. The report suggested a monitoring program which could make a valid comparison possible for the operation of units 2 and 3 .

In summary, the San Onofre 1 monitoring data indicates that fish populations increased in the vicinity of a warm discharge, and no change was observed in the number of species. l'here is not sufficient data to evaluate any change in local fish population due to the operation of a plant, nor is there sufficient data to evaluate the effect of a plant on the population dynamics of the nearby ocean. 
Table 4. Fish collected in bottom nets at San Onofre unit 1 in 1975

\begin{tabular}{|c|c|c|c|c|c|}
\hline & March & June & September & December & Total \\
\hline Near discharge & & & & & \\
\hline Number of fish & 417 & 641 & 214 & 598 & 1870 \\
\hline Number of species & 20 . & 23 & 17 & 20 & - \\
\hline \multicolumn{6}{|l|}{ In control area ${ }^{a}$} \\
\hline Number of $\mathrm{fish}$ & 253 & 383 & 208 & 168 & 1012 \\
\hline Number of species & 24 & 23 & 19 & 19 & -- \\
\hline
\end{tabular}

${ }^{a}$ Control area $8 \mathrm{~km}$ downcoast from plant. 


\section{ECONOMICS}

Once-through systems historically have been more economical than the various closed-cycle alternatives. This may or may not be true for offshore submerged systems for NECs.

The cost of an offshore system will be highly site dependent. The offshore concept for dissipating the large amount of heat from an NEC depends upon access to the large amount of cool water which is available at greater depths than have been utilized heretofore. The length of the conduits required to reach this deeper water is site dependent, and the cost of the conduits depends strongly on the type of rock or soil at the site. The cost of water distribution within the NEC is also dependent on the topography and soll. While it is therefore not possible to attach a price tag to an offshore system as one can to a cooling tower, considerable is known concerning the cost factors of offshore systems. Let us first examine the characteristics of several systems designed for current plants.

\subsection{Current Offshore System Designs}

The cost-determining characteristics of three offsliute systein designg are given in Table 5, along with the utfl1ty's estimate of the cost of the once-through system relative to the cost of the closed-cycle system considered most suitable for the site. In the case of the Perry, $\mathrm{OH}$, plant, the closed-cycle system was the alternative chosen for construction (for institutional rather than economic reasons).

The estimated costs of these systems range from less than half the cost of a closed-cycle system at San Onofre to nearly an equal cost at Seabrook. Cost ratios are based on lifetime costs, including operating costs and penalties for capacity losses.

The San Onofre system was relatively low cost because relatively deep water was close to shore, there was no plant setback from the shoreline, so that onshore conduit length was negligible, and the soil conditions were favorable for laying buried pipeline. The estimated cost for this system should be reliable because the utility has already constructed a smaller offshore system for unit 1 at the same site. 
Table 5. Characteristics of several designs for offshore heat dissipation systems

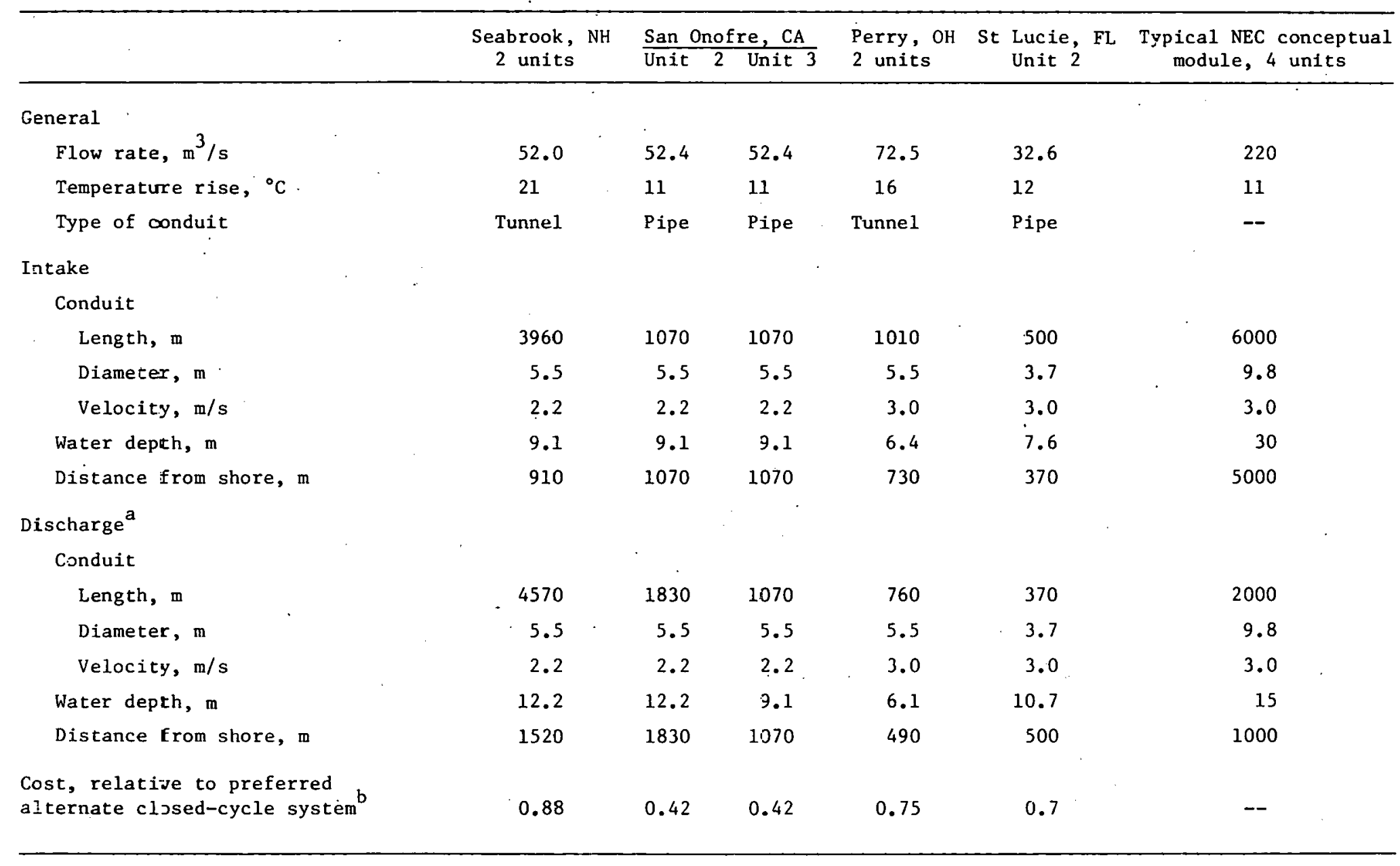

at first po:t.

${ }^{b}$ Including present worth of annual costs and capacity penalties. 
The Perry system design was for water tunnels in a shale substrate. The cost of the actual tunnelling was estimated to be only $15 \%$ of the construction cost of the cooling system. Presumably, then the system could have been extended further from shore to somewhat deeper water without a large increase in costs.

The Seabrook system, based on tunneling through rock, was relatively expensive because of the site. The site is a considerable distance from open ocean, and two-thirds of the tunnel distance is inshore. No doubt to hold down tunneling and pumping coses, this system was desighied for a relatively large $\Delta \mathrm{T}$ and low flow rate. The estimated overall cost is very close to that of a closed-cycle system.

\subsection{Costs of an NEC System}

The characteristics of what might be a typical NEC system module are given in the last column of the table. The economic optimum diameter for tunneling appears to be about $10 \mathrm{~m}$, and a tunnel of this size is about right for four units; therefore, the data are given for a four-unit module of the system shown in Fig. 1. In length of tunnels, the NEC module is very similar to the Seabrook system, and the cost of the module is probably in the same range. The use of one tunnel for four (rather than 2) units would save on both tunneling and pumpling custs. However, the installation of intake and discharge structures in somewhat deeper water (considerably deeper for the intake) would increase costs moderately. The equipment and procedures usually employed in coastal construction work (e.g., jack-up barges) can be used in water depths up tó about $35 \mathrm{~m}$ at moderate cust. Work in deeper water is feasible, but would probably jump costs to a higher level, and does not appear warranted for heat dissipation systems.

As already mentioned, offshore system costs are likely to be very site dependent. It appears that, for favorable sites, the cost of an offshore module can be less, bit probably not greatly less, than the cost of a closed-cycle system. For less favorable sites, the cost could equal or exceed the cost of closed-cycle systems. In the latter case, the offshore alternative might be selected for reasons not strictly economic, such as lower atmospheric and visual impact, or an advantage in the site area required. 


\subsection{Water Conduits}

Meaningful costs for a water conduit system must be referred to a specific site. However, considerable generic information is available. ${ }^{13}$

In favorable locations for each, the cost of buried pipeline exceeds the cost of tunnels by about the cost of installation of the pipeline (for Seabrook, pipeline was estimated to cost about $40 \%$ more than tunnels). Installation of pipeline can be costly where surface obstructions such as roads and railroads must be crossed, and restoration costs may be high where recreational or wildlife areas are disturbed. Large pipeline sections (10 $\mathrm{m}$ diam) are not generally transportable, but can be fabricated on or near the site and may be conveniently moved by barge.

Tunneling has the advantage of not disturbing the land surface or the shoreline, except for test boring. Modern tunneling practice requires a heavy concentration of test boring along the route; closely spaced borings, although expensive, can save money in tunneling by avoidance of bad rock. Most tunnels are concrete lined, but where rock is adequately self-supporting, about one-third the cost of the tunnel can be saved if lining is not required. The type of rock present largely determines the economics of tunneling. Tunneling costs increase by factors of two or three for hard rock or sections of fractured or nonsupporting rock.

Techniques for tunneling through unconsolfdated and/or water-saturated soils are within the present state of the art, but are relatively expensive. However, the terchnology of tunneling is advancing rapidly and the alternative of tunneling rather than laying buried pipeline should be examined for any potential site.

\subsection{Water Distribution}

The layout of an NEC would require that some of the power plants be located at some distance from the pumphouse, requiring water conduits for distribution. Tunnels or burfed pipelines would be suitable, but for many sites open channels could be used at a considerable saving in cost. Once the shore zone has been crossed with underground conduits, the use of open condults on-slle way be envirommentally innocunus and relatively inexpensive. 


\section{REFERENCES}

1. U.S. Nuclear Regulatory Commission, Nuclear Energy Center Site Survey, 1975, NUREG-00001-ES, January 1976.

2. D. F. Cope and H. F. Bauman, Expansion Potential of Existing Nuclear Power Station Sites, ORNL/TM-5927 (November 1977).

3. A. A. Patrinos and H. W. Hoffman, "Atmospheric Effects of Nuclear Energy Centers (AENEC) Program Annual Technical Progress Report for Period July 1975-September 1976," ORNL/TM-5778, 1977.

4. U.S. Atomic Energy Commission, Final Environmental Statement, Seabrook Slulivur Uribls I and \%, locket Nos. 50-443 and 50-444 (December 1974).

5. U.S. Nuclear Regulatory Commission, Final Environmontal Statement Related to Operation of San Onofre Nuclear Generating Station Units 2 and 3, Docket Nos. 50-361 and 50-362.

6. U.S. Nuclear Regulatory Commission, Final Environmental Statement Related to the Proposed Manufacture of Floating Nuclear Power Plants. Part II. A Generic Environmental Statement Considering the Siting and Operation of Floating Nuclear Power Plants, Offshore Power Systems, NUREG-75/113, Docket.No. STN-437, September 1976.

7. U.S. Nuclear Regulatory Commission, Revised Draft Environmental Statement for AtZantic Generating Station, NUREG-0058, Docket Nos. STN 50-477 and STN 50-478, October 1976.

8. J. S. Suffern, Physical Effects of Entrainment: Current Researsh at. Uak Kidge National Laboratory, ORNL/TM-5948, August 1977.

9. U.S. Atomic Energy Commission, Environmental Statement, Perry Nuclear Power Plant, Units 1 and 2, Docket Nos. 50-440 and 50-441, Apri1 1974.

10. R.C.Y. Koh, N. H. Brooks, E. J, List, and E. .T. Wn1 anski, Hydrauli.o Modeling of Thermal. Outfall Diffusers for the San Onofre Nuclear Power Plant, Report No. KH-R-30, W. M. Keck Laboratory of Hydraulics and Water Resources, California Institute of Technology, Pasadena, California, January 1974.

11. M. S. Isaacson, R.C.Y. Koh, E. J. List, Hydraulic Investigations of Thermal Diffusion during Heat Treatment Cycles, San Onofre Nuclear Generating Station, Units 2 and 3, California Institute of Technology, Technical Memorandum 76-2, December 1976.

12. S. M. Adams et al., A Critical Evaluation of the Nonradiological Environmental Technical Specifications, Vol. 4: San Onofre Nuclear Generating Station Unit 1; ORNL/NUREG/TM-72 (Vol. 4 of ORNL/NUREG/TM-69), June 1977. 
13. Information on construction methods and costs for underground water conduits compiled by Millard L. Myers, ORNL Engineering Technology Division, from informal communications with various construction companies and architect-engineering firms. 
ORNL/TM-6435

Dist. Category UC-12

\section{Internal Distribution}

1. S. M. Adams

2. T. D. Anderson

3. S. I. Auerbach

4. J. A. Auxier

5. Seymour Baron

6-15. H. F. Bauman

16. S. E. Beal1

17. H. I. Bowers

18. R. W. Brockson

19. C. C. Burwe11

20. J. B. Cannon

21. R. S. Carlsmith

22. R. G. Chenoweth, Jr.

23. C. V. Chester

24-28. T. E. Cole

29. W. E. Cooper

30: D. F. Cope (Consultant)

31. W. B. Cottre11

32. C. C. Coutant

33. R. M. Davis

34. D. M. Eissenberg

35. A. H. Eraslan

36. H. F. Falkenberry

37. W, Fulkerson

38: S. B. Gough

39. J. F. Harvey

40. R. F. Hibbs

41. S. G. Hildebrand

42. ก. H. Kl.epper
43. R. L. Kroodsma ,

44. D. K. Kumar

45. Milton Levenson

46. J. M. Loar

47. J, S. Mattice

48. H. A. McLain

49. R. B. McLean

50. M. L. Myers

51. H. Postma

52. M, W. Rosenthal

53. T. H. Row

54. F. S. Sanders

55. Dunlap Scott

56-80. I. Spiewak

81. W. G. Stockdale

82. A. T. Szluha

83. R. E. Thoma

84. H. E. Trammel1

85. D. B. Trauger

86. W. Van Winkle

87. A. J. Witten

88. G: T. Yeh

89. H. E. Zitte1

90-93. Central Research Library

94. Document Reference Section

95-97. Laboratory Records

98. Laboratory Records, RC

99. ORNL Patent Office

\section{External Distribution}

100. E. S. Beckford, Director, Nuclear Power Development Division; DOE, Germantown, MD 20767

101. A. P. D'Zmura, Power Development Division, DOE, Washington, DC 20545

102. R. W. A. LeGassie, Office of Energy Research, DOE, 20 Massachusetts Ave., Washington, DC 20545

103. W. F. Savage, Advanced Systems and Materials Production Division, DOE, B-107, Washington, DC 20545

104. S. Strauch, Acting Deputy Director, Fuel Cycle Evaluation, DOE, Germantown, MD 20767 
105. R. L. Egli, Director, Reactor Division, DOE, Oak Ridge

106. J. A. Lenhard, Director, Research \& Technical Support Division, DOE, Oak Ridge

107. David Bodde, DOE, Director, Office of Nuclear Policy, Federal Bullding, 20th and Pennsylvania Ave., Washington, DC 20461

108. Nea1 Goldenberg, DOE, Acting Assistant Director, Office of Advanced Systems and Materials Production Division, B-107, Washington, DC 20545

109. D. S. Crestin, National Marine Fisheries Service, Gloucester, MA

110. D. P. DeSylva, Institute of Marine Science, Miami, FL

111. C. M. Fetterolf, Jr., Great Lakes Fishery Commission, Ann Arbor, MI

112. J. J. Reisa, Jr., Council on Environmental Quality, Executive office of the President, Washington, DC

113. Dave Thomas, Ichthyological Associates, Inc., Box 70-D, P.D. 2, Absecon, NJ 08201

114. C. R. Hickey, Nuclear Regulatory Commission, Washington, DC 20555

115-116. D. Mathur, T. Robbins, Ichthyological Associates, Inc., P.0. Box 12, Drunure, PA 17518

117. Atomics Internationa1, Attn. Library, Box 309, Canoga Park, CA 91304

118. Westinghouse Electric Corp., Attn. Librarian, Bettis Atomic Power Laboratory, P.0. Box 79, West Mifflin, PA 15122

119. Brookhaven National Lab, Attn. Research Lib., Ref. Section, Information Division, Upton, LI, NY 11973

120. Center for Energy and Environment Research, Attn. Training and Information Div., Caparra Heights Station, San Juan, PR 00935

121. Environmental Protection Agency, Attn. Director, Env. Monitoring and Support Library, P.0. Box 15027, Las Vegas, NV 89114

122. General Electric Company, Attn. Librarian, Vallecitos Atomic Lab, P.O. Box 846, Pleasanton, CA 94566

123. University of California, Attn. Library, Bldg. 50, Room 134, Lawrence Berkeley Laboratory, Berkeley, CA 94566

124. General Electric Company, Attn. Division Librarian, Nuclear Energy Division, Post Office Box 1131, San Jose, CA 95108

125. University of California, Lawrence Livermore Laboratory, Technical Information Dept., L-3, P.0. Box 808, Livermore, CA 94550

126. Science Application, Inc., Attn. Dr. E. Straker, P.0. Box 2351, La Jolla, CA 92037

127. Tennessee Valley Authority, Attn. Energy Research Section, 1360 Commerce Union Bank Bldg., Chattanooga, TN 37401

128. Don G. Allen, President, Yankee Atomic Electric Company, 20 Turnpike Road, Route 9, Westborough, MA 01581

129. Wells P. Allen, Senior Vice President, New York State Electric and Gas Corp., 4500 Vestel Parkway, E., B1nghamton, NY 13902

130. Ralph Bean, Chairman, New England Planning Commission, Central Main Power Company, Edison Drive, Augusta, ME 04330

131. Robert 0. Bigelow, Planning Engineer, New England Electric System, 20 Turnpike Road, West Burrow, MA 01581

132. Walter Brown, Administrator-Manager, National Electric Reliability Council, Research Park, Terhune Road, Princeton, NJ 08540

133. Saul Burstein, Senior Vice President, Wisconsin Electric Power Company, 231 West Michigan Street, Milwaukee, WI 53201 
134. Bill Colston, San Diego Gas \& Electric Company, P.0. Box 1831, San Diego, CA 92112

135. John T. Conway, Executive Assistant to the Chairman, Consolidated Edison Company, New York City, NY

136. E. N. Cramer, Engineer for Advanced Engineering Systems, Southern California Edison Company, P.0. Box 800, Rosemead, CA 91770

137. Ed H. Crews, Jr., Vice President, Construction and Engineering, South Carolina Electric and Gas Company, 328 Main Street, Columbia, SC 29218

138. L. C. Dale, Chief Engineer, Duke Power Company, 422 South Church Street, Charlotte, NC

139. Richard M. Eckert, General Manager, Engineering and Construction, Public Service Electric and Gas, 80 Park Place, Newark, NJ 07101

140. A. V. Dienhart, Vice President of Engineering, Northern States Power Company, 414 Nicolett Ma11, Minneapolis, MN 55401

141. W. J. Ferguson, Vice President, Engineering \& Construction, Puget Sound Power \& Light Company, Puget Power Building, Bellevue, WA 98009

142. Terry A. Ferrar, 312 Ridge Avenue, State College, PA 16801

143. John W. Gore, V.P., Engineering \& Construction, Baltimore Gas and Electric Co., Gas and Electric Bldg., Baltimore, MD 21203

144. Jack Gilleland, Tennessee Valley Authority, Power building, 540 Market Street, Chattanooga, I'N 37401

145. Harold Harty, Battelle Pacific Northwest Laboratories, Battelle Boulevard, Richland, WA 99352

146. Pat Howe, Director, Environmental Services, Carolina Power and Light Company, Raleigh, NC

147. Herbert Jacobs, Energy Parks Coordinator, Governor's Energy Council, State Capital, Harrisburg, PA 17120

148. Steven Jellinek, Staff Director, Council on Environmental Quality, 722 Jackson Place, N.W., Washington, DC 20006

149. L. F. Lischer, Vice President, Commonwealth Edison Company, One First National P.laza, P.0. Box 767, Chicago, IL 60690

150. Chuck Mangan, Manager of Production and Plant Engineering, Niagara Mohawk Power Company, 300 Erie Boulevard, West Syracuse, NY 13202

151. Richard A. Mulford, Project Manager, Mechanical Engineering Division, Philadelphia Electric Company, 2301 Market Street, Philadelphia, PA 19101

152. James I. Owens, Project Manager, Summit Nuclear Power Plant, Delmarva Power and Light Company, 800 King Street, Wilmington, DE $19 \dot{8} \dot{9} \dot{y}$

153-157. K. J. Nemeth, Executive Director, Souther States Energy Board, Une Exchange Place, Sulle 1230, Atlanta, GA 30338

158. Stanley Ragone, Senior Vice President for Power, V1rginia Electric and Power Company, 700 East Franklin Street, Richmond, VA 23261

159. John Randazza, Assistant Vice President, Central Main Power Company, Edison Drive, Augusta, ME 04330 
160-164. John L. Watson, Executive Director, Western Interstate Energy Board, 2500 Stapleton Plaza, 3333 Quebec, Denver, CO 80207

165. John Saeger, Project Manager, Energy Park Development, Pennsylvania Power and Light Company, 2 North 9 th Street, Allentown, PA 18101

166. B. W. Shackelford, Vice President for Planning and Research, Pacific Gas and Electric Company, 77 Beale Street, San Francisco, CA 94106

167. Don Sinville, Vice President, Public Service Company of New Hampshire, 1000 Helm Street, Manchester, NH 03105

168. Jack Stiles, Vice President for Power Planning, Pacific Power and Light Company, Public Service Building, Sixth Avenue, Portland, UK 97204

169. Gerald I. Stillman, Principal Research Development Engineer, Power Authority of the State of New York, 10 Columbus Circle. New York, NY 10019

170. Jack Thorpe, Chief Engineer, General Public Utilities Company, 80 Pine Street, New York, NY 10005

171. D. E. Vandenburgh, Vice President, Yankee Atomic Electric Company, 20 Turnpike Road, Route 9, Westborough, MA 01581

172. Don Voyles, Vice President, Duke Power Company, 422 South Church Street, Charlotte, NC

173. Dean M. Golden, Southern California Edison Company, P.0. Box 800 , Rosemead, $\mathrm{CA} 91770$

174. W. A. Williams, Jr., Vice President, South Carolina Public Service Authority, 223 N. Live Oak Drive, Moncks Corner, SC 29461

175. Neil H. Woodley, Chairman, Generation Resources Investigation Team, Portland General Electric Company, Electric Building, 621 S.W. Alder Street, Portland, OR 97205

176. E. Eric Adams, Massachusetts Inst. of Tech., Cambridge, Mass. 02139

177. T. E. Edinger, 63 Crestline Road, Strafford, Pa, 19087

178. A. J. Policastro, Argonne National Laboratory, Illinois 60435

179. D. W. Pritchard, Chesapeake Bay Institute, Johns Hopkins Univ., Baltimore, Maryland

180. Mostafa A. Shirazi, U.S. Environmental Protection Agency, Corvallis, Oregon 97330

181. Keith D. Stolzenbach, Massachusetts Inst. of Tech., Cambridge, Mass. 02139

182-488. For distribution as shown in TID-4500 under UC-12, Heat Rejection and Utilization 